\title{
Sapling herbivory, invertebrate herbivores and predators across a natural tree diversity gradient in Germany's largest connected deciduous forest
}

\author{
Stephanie Sobek · Christoph Scherber • \\ Ingolf Steffan-Dewenter · Teja Tscharntke
}

Received: 13 June 2008 / Accepted: 27 January 2009 / Published online: 24 February 2009

(C) Springer-Verlag 2009

\begin{abstract}
Tree species-rich forests are hypothesised to be less susceptible to insect herbivores, but so far herbivorydiversity relationships have rarely been tested for tree saplings, and no such study has been published for deciduous forests in Central Europe. We expected that diverse tree communities reduce the probability of detection of host plants and increase abundance of predators, thereby reducing herbivory. We examined levels of herbivory suffered by beech (Fagus sylvatica L.) and maple saplings (Acer pseudoplatanus L. and Acer platanoides L.) across a tree species diversity gradient within Germany's largest remaining deciduous forest area, and investigated whether simple beech or mixed stands were less prone to damage caused by herbivorous insects. Leaf area loss and the frequency of
\end{abstract}

Communicated by Diethart Matthies.

Electronic supplementary material The online version of this article (doi:10.1007/s00442-009-1304-2) contains supplementary material, which is available to authorised users.

S. Sobek $(\varangle) \cdot$ C. Scherber · T. Tscharntke Agroecology, Department of Crop Science, University of Göttingen, Waldweg 26,

37073 Göttingen, Germany

e-mail: ssobek@gwdg.de

I. Steffan-Dewenter

Population Ecology Group,

Department of Animal Ecology I, University of Bayreuth,

Universitätsstr. 30, 95440 Bayreuth, Germany

Present Address:

S. Sobek

Department of Biology, University of Western Ontario,

London, ON N6A 5B7, Canada galls and mines were recorded for 1,040 saplings ( $>13,000$ leaves) in June and August 2006. In addition, relative abundance of predators was assessed to test for potential topdown control. Leaf area loss was generally higher in the two species of maple compared to beech saplings, while only beech showed a decline in damage caused by leafchewing herbivores across the tree diversity gradient. No significant patterns were found for galls and mines. Relative abundance of predators on beech showed a seasonal response and increased on species-rich plots in June, suggesting higher biological control. We conclude that, in temperate deciduous forests, herbivory-tree diversity relationships are significant, but are tree species-dependent with bottom-up and top-down control as possible mechanisms. In contrast to maple, beech profits from growing in a neighbourhood of higher tree richness, which implies that species identity effects may be of greater importance than tree diversity effects per se. Hence, herbivory on beech appeared to be mediated bottom-up by resource concentration in the sampled forest stands, as well as regulated topdown through biocontrol by natural enemies.

Keywords Diversity-functioning relationships . Leaf damage $\cdot$ Mines $\cdot$ Multitrophic interactions · Plant-animal interactions

\section{Introduction}

The relationship between plant biodiversity and ecosystem functioning is a central question in ecology (Hooper et al. 2005; Balvanera et al. 2006; Cardinale et al. 2006), but so far the majority of studies have focused on plant productivity in experimental grasslands. Research on the effects of plant diversity on other trophic levels, for example insect 
herbivores as primary consumers, has a long tradition in agricultural habitats (reviewed in Andow 1991), while natural habitat types have only recently begun to be considered. In most of these studies, reduced insect herbivory was observed with increased plant diversity, both in agricultural (Risch et al. 1983) and grassland (Unsicker et al. 2006) or forest habitats (Jactel et al. 2006; Jactel and Brockerhoff 2007; Kaitaniemi et al. 2007). However, some authors found the opposite (Vehviläinen et al. 2006) or no effect at all (Scherber et al. 2006), and the outcome often appears to be species dependent (Jactel and Brockerhoff 2007; Vehviläinen et al. 2007). Identity of the observed plant species and of species in the surrounding community, as well as host specificity of herbivores, have been shown to affect the herbivory-plant diversity relationship (Koricheva et al. 2006; Unsicker et al. 2006; Jactel and Brockerhoff 2007). According to data from other invertebrate herbivores (e.g. molluscs), diversity-herbivory relationships are not controlled by plant diversity in the local neighboorhood, but by plant diversity observed on community level (Hanley 2004).

Lower susceptibility of species-rich plant communities to insect herbivores, also described as associational resistance (Tahvanainen and Root 1972; Karban 2007; Sholes 2008), can be explained with two well-established concepts: the resource concentration hypothesis (Tahvanainen and Root 1972; Root 1973) and the enemies hypothesis (Root 1973; Russell 1989). The resource concentration hypothesis is based on the assumption that specialist herbivores accumulate in dense patches of their host plants and reside there if the conditions are favourable (Root 1973). In diverse plant communities, individual plant species are often less prone to herbivore infestation, because host-finding is hindered due to lower host plant densities. Plants growing in small patches of low abundance appear to be structurally or chemically masked by their surrounding neighbours (Mauchline et al. 2005; Karban 2007). According to the enemies hypothesis, a diverse matrix of flowering plants in species-rich assemblages offers alternative prey, accessory food (e.g. pollen, nectar) and various shelter options for predators and parasitoids (Root 1973; Russell 1989, Jactel et al. 2005). This increased structural diversity enhances natural enemy abundance and functional diversity, finally resulting in effective biological control of specialist herbivores.

More recently, a mechanism called associational susceptibility (White and Whitham 2000) has been suggested to explain why in some studies no reduction, or even an increase, in herbivory with increased plant diversity was found. According to this idea, generalist herbivores are thought to spill over from preferred plant species to less favoured hosts in the adjacent neighbourhood (Jactel et al. 2005; Carnus et al. 2006).
In diversity gradients across forest ecosystems, most studies carried out so far primarily focused either on specific forest pests (e.g. Su et al. 1996; Jactel et al. 2002) or generalist insect herbivores (Vehviläinen et al. 2006). Predator abundance was not included in these investigations, although it is sometimes referred to as a possible explanation for observed differences in herbivore damage (Su et al. 1996), and has only recently gained more interest in studies of forest herbivory (Jactel et al. 2006; Vehviläinen et al. 2008).

The impact of herbivore damage on plant survival is strongest in early developmental stages (Maron 1997; Hanley and Fegan 2007), and during ontogeny defensive plant traits are subject to change (Boege and Marquis 2005). In forest ecosystems, most studies have focused on herbivore damage in the canopy tree layer, but naturally grown saplings have rarely been used as target organisms for observation. Although early-stage tree damage caused by large herbivores (i.e. deer browsing) has been intensively investigated (Hester et al. 2000), data are scarce for insect herbivory. Studies usually only include low hanging branches of trees and larger saplings (e.g. Le Corff and Marquis 1999; Forkner et al. 2006), rather than surveys of whole saplings in an early stage of regeneration. For juvenile trees at this stage, only data for experiments with planted trees exist (Ladd and Facelli 2005; Löf et al. 2005; Massey et al. 2006; Norghauer et al. 2008), while in situ observations of individuals already established in the natural forest environment are so far missing. Although experiments with planted trees can be of great value for manipulating diversity per se, they are insufficient in imitating the age structure and spatial heterogeneity of the natural forest canopy and understory (Leuschner et al. 2009).

If trees are damaged by herbivores, growth and productivity of infested individuals is either reduced, eventually leading to a disadvantage in competition, or reinforced by overcompensation (Ayres et al. 2004; Zeide and Thompson 2005; Huttunen et al. 2007). Damage may also enhance vulnerability to fungal or bacterial pathogens (Kluth et al. 2001). Insect herbivory on saplings might, thus, affect forest regeneration and play an important role in the establishment of future forest communities. No studies have been published so far on sapling herbivory and tree diversity in exclusively deciduous forests of the temperate climate zone. In particular, it is remarkable that no studies have investigated this relationship using Fagus sylvatica L., which has been declared to be "the most successful Central European plant species" in its manner of expansion across the continent (Leuschner et al. 2006).

In this study, we addressed this research gap by examining tree diversity effects on herbivory of young instead of mature trees and also included a survey of invertebrate herbivores predators. We used a gradient ranging from simple 
beech to diverse forest stands within a temperate, deciduous, semi-natural forest in Central Europe, and studied leaf damage in beech and maple saplings across this gradient. We hypothesised that herbivory rates decrease with increased tree diversity due to host-finding limitations, and that relative abundance of predators increases, thereby enhancing top-down control of herbivorous insects. We also tested for host plant specific differences in herbivore and predator responses. Specifically, we addressed the following questions: (1) Which sapling species is affected most by leaf-chewing insects, and how severe is the extent of leaf area loss? (2) Are diverse forest stands less susceptible to insect herbivores than simple stands? (3) How is the frequency and distribution of galls and mines across the gradient? (4) How is the relative abundance of predators and parasitoids related to tree diversity and the herbivore damage patterns?

\section{Materials and methods}

Study area

The study was carried out in Germany's largest remaining connected semi-natural deciduous forest, the Hainich National Park, Thuringia. The Hainich forest covers a total area of 16,000 ha. Approximately half of it was designated national park in 1997 (Nationalpark Hainich; http:// www.nationalpark-hainich.de).

All research plots were located in the north-eastern part of the protected area close to Weberstedt (approximately $51^{\circ} 1^{\prime} \mathrm{N}, 10^{\circ} 5^{\prime} \mathrm{E}$ ) and the average distance between plots was $4.9 \mathrm{~km}$. The study site had an elevation of $350 \mathrm{~m}$ asl and a temperate climate, with an average temperature of $+7.5^{\circ} \mathrm{C}$ (1973-2004, Deutscher Wetterdienst). Average annual temperature in 2006 was $9.4^{\circ} \mathrm{C}$ (Meteomedia 2006). Mean annual precipitation is $590 \mathrm{~mm}$ (1973-2004, Deutscher Wetterdienst), and was $518 \mathrm{~mm}$ in 2006 (Meteomedia 2006). The predominant soil type was stagnic luvisol on loess-limestone as parent material.

Plots were established across an existing gradient of canopy tree diversity ranging from simple beech to mixed forest stands with a varying number of deciduous tree species [Electronic supplementary material (ESM) S1]. The mild climate in the area favours a wide variety of deciduous trees. The dominant tree species in the Hainich forest are Fagus sylvatica L. (Fagaceae), Tilia platyphyllos Scop., T. cordata Mill. (both Tiliaceae) and Fraxinus excelsior L. (Oleaceae). The species Carpinus betulus L. (Betulaceae), Acer campestre L., A. platanoides L., A. pseudoplatanus L. (all Aceraceae), Prunus avium (L.), Sorbus torminalis L. (both Rosaceae), Quercus robur L. (Fagaceae), and Ulmus glabra Huds. (Ulmaceae) occur less frequently. Coniferous trees such as Abies alba Mill., Picea abies (L.) H. Karst., Pinus sylvestris L. and Larix decidua Mill. (all Pinaceae) are scarce. All conifers are logged to regain a late successional stage of deciduous forest throughout the protected area.

Site selection, assessment of herbivore damage and insect communities

Nine observation sites were established in spring 2005. To ensure comparability, all plots were selected to share equal major stand characteristics, such as stagnic luvisol on loess soils, flat elevation, absence of canopy gaps, and not having been logged for at least 40 years. On each site, an observation plot measuring $50 \times 50 \mathrm{~m}$ was fenced with a $2-\mathrm{m}$-tall fence constructed of narrow mesh wire and wooden and steel pickets. The fence was build to exclude browsing and trampling by ungulates (e.g. wild boars, fallow deer, roe deer and red deer). To exclude small mammals like rabbits and hares from accessing the observation sites, the lower part of the mesh-wire was burrowed into the soil. To ensure that observed leaf damage was caused by invertebrates only, the exclosures where installed in 2005 , one year prior to estimation of herbivory. The exclosures were effective in excluding large and small herbivorous mammals (ungulates, rabbits and hares) and vertebrate predators (i.e. foxes) from the plots (no signs of browsing, no scat found in 2006).

All herbivory related parameters were assessed in late June and late August 2006. This timing was chosen to allow for a sufficient time span since leave flush in early May, in which measurable herbivore damage levels could develop. Prior to June, herbivore damage was observed only exceptionally and hence not estimated. Species identity and relative abundance of tree saplings were recorded in six random $5 \times 5 \mathrm{~m}$ subplots inside each $50 \times 50 \mathrm{~m}$ main plot (Mölder et al. 2009), while herbaceous plant species were identified in the $5 \times 5 \mathrm{~m}$ subplots and additionally in a larger $20 \times 20 \mathrm{~m}$ subplot per $50 \times 50 \mathrm{~m}$ plot (Mölder et al. 2006, 2008).

Saplings (young trees $<75 \mathrm{~cm}$ tall) of common beech (Fagus sylvatica), Norway maple (Acer platanoides) and sycamore maple (A. pseudoplatanus) were examined for signs of invertebrate herbivory (leaf area loss caused by leaf-chewing insects, presence of galls and mines). The three species were abundant on all plots, but the proportion of beech saplings declined with increased canopy tree diversity, while the abundance of Norway maple increased and the abundance of sycamore maple remained constant (ESM S1 and S2). Diversity of tree saplings was marginally correlated with canopy tree diversity (Pearson's $\rho=0.66$, $P=0.055$ ). To meet the prerequisites of stratified random sampling, each $50 \times 50 \mathrm{~m}$ plot was equally divided in four 
quarters, and ten individuals of each sapling species were randomly drawn from these subplots. Hence, on each plot, 120 saplings ( $=40$ per species) were inspected for leaf area loss and presence of galls and mines. An exception was made for Norway maple, which was absent on one plot and, hence, not sampled on this plot.

In total, 1,040 saplings (13,728 leaves) were examined. Leaf area loss caused by leaf-chewing invertebrates was estimated in situ by visual inspection of each single leaf using percentage score classes modified after Wint (1983); $0=$ no damage $, \quad 1=1-5 \%, \quad 2=6-30 \%, \quad 3=31-50 \%$, $4=51-70 \%, 5=71-90 \%, 6=90-100 \%$. Damage rates were calculated per sapling by summing up the score class means for each leaf. The sum was then divided by the number of leaves per sapling. We furthermore punched eight leaves of every tree species per plot with a hole puncher in June 2006. The length of the leaves, and of two undamaged control leaves, and the diameter of the holes were measured. Measurements were repeated in August 2006. The results showed that leaf growth did not affect the extent of leaf area loss (data available upon request).

Furthermore, the presence or absence of galls and mines was noted for each leaf and damage was expressed as proportion of infested leaves per plant. Additionally the number of leaves, sapling complexity (= number of primary branches), sapling height and percentage vegetation cover in a $1 \times 1 \mathrm{~m}$ sampling quadrat surrounding the sapling were recorded. On each plot, abundance and species identity was assessed for all canopy trees with a diameter breast height $(\mathrm{dbh})>7 \mathrm{~cm}$.

Each sapling used for the estimation of herbivory was also carefully inspected for the presence of invertebrates, which were identified in situ to at least order level. For a more comprehensive survey of the invertebrate fauna present, directly adjacent to each plot 30 beating samples (10 sapling replicates of each sapling species) were taken from randomly chosen saplings to ensure that the fauna on the research plots remained undisturbed. Beating samples were obtained by beating the saplings with a wooden club against a fabric funnel attached to a collecting jar. This resulted in a total of 520 beating samples. Samples were stored at $-19^{\circ} \mathrm{C}$ until processing.

Sample processing and data analyses

Invertebrates were separated from plant material and debris and then preserved in $70 \%$ ethyl alcohol. When species level identification was impossible, individuals were assigned to the lowest possible taxonomic level (at least to order). All specimens, including the individuals observed in situ, were either grouped into the feeding guilds 'chewers', 'suckers', 'predators', and 'parasitoids', or classified as 'others' (ESM S3). The two groups of natural enemies, predators and parasitoids, were combined for further analyses and are for simplification hereinafter referred to as predators.

Data were analysed using the statistical software package R 2.6 (R Development Core Team; http://www.R-project.org). Normality of raw data was evaluated with Shapiro-Wilk tests followed by arcsine square-root transformation of all proportion data prior to further analyses. To analyse whether tree species generally differed in leaf area loss, one-way analysis of variance (ANOVA) was performed with tree species as a categorical explanatory variable, and a Tukey's honestly significant difference test (Tukey HSD) as a post-hoc comparison.

To account for individual proportions of tree species as well as for the number of species (Magurran 2004), canopy tree diversity of the nine research plots was expressed as Shannon index based on stem counts of all individuals with a dbh $>7 \mathrm{~cm}$. Tree diversity a priori influences a range of other abiotic and biotic plot conditions (Mölder et al. 2006), and some of them might also impact the observed herbivory patterns. No relationship with photosynthetic active radiation (PAR) was found, but soil $\mathrm{C} / \mathrm{N}$ ratios were higher in simple beech stands, whereas the number of molluscs was higher in the most diverse forest stands (ESM S2).

Linear mixed effects models (LMEs; Pinheiro and Bates 2000) with leaf area loss, frequency of mines, frequency of galls and predator abundance as response variables were fitted separately for all three tree species using maximum likelihood. The significance of the fixed-effect terms in each model was tested using conditional $F$ tests with terms tested sequentially in the order in which they had been added to the model. LMEs are advantageous compared to simple ANOVA models because they allow the inclusion of multiple nested random effects terms to account for temporal and/or spatial pseudoreplication. Before construction of the maximal model, explanatory variables (Shannon index, number of sapling tree species, number of herbaceous plant species, PAR, soil $\mathrm{C} / \mathrm{N}$, proportion of tree species in the canopy, proportion of tree species in the understory, sapling height, sapling complexity) were analysed for correlations, and all variables with a pairwise correlation coefficient $\geq 0.6$ were not included within the same model to minimize possible effects of multicollinearity. Shannon index was introduced as fixed variable after controlling for the variance explained by sapling complexity (number of primary branches). The maximal model was fitted with the following sequence: fixed effects $=$ date, sapling complexity, Shannon index, Shannon index $\times$ date; random effects were included as differences between slopes (dates) and intercepts (plots). After fitting the maximal model, model simplification was accomplished by stepwise deletion of non-significant terms based on differences in Akaike's 
Table 1 Simplified linear mixed effects models performed on different types of leaf damage and percent predator abundance on three tree sapling species on forest plots in the Hainich National Park

\begin{tabular}{|c|c|c|c|c|c|c|c|c|c|c|c|c|c|}
\hline \multirow[t]{2}{*}{ Response variable } & \multirow[t]{2}{*}{ Effect } & \multicolumn{4}{|l|}{ Beech } & \multicolumn{4}{|c|}{ Norway maple } & \multicolumn{4}{|c|}{ Sycamore maple } \\
\hline & & Num $d f$ & Den $d f$ & $F$ & $p$ & Num $d f$ & Den $d f$ & $F$ & $p$ & Num $d f$ & Den $d f$ & $F$ & $p$ \\
\hline \multicolumn{14}{|l|}{ Leaf area loss } \\
\hline & Date & 1 & 8 & 49.15 & $<0.001$ & 1 & 7 & 9.58 & 0.018 & 1 & 8 & 8.77 & 0.018 \\
\hline & Sapling complexity & - & - & - & $\dagger$ & - & - & - & $\dagger$ & 1 & 7 & 26.59 & 0.001 \\
\hline & Shannon index & 1 & 7 & 16.6 & 0.005 & - & - & - & $\dagger$ & - & - & - & $\dagger$ \\
\hline & Date $\times$ Shannon index & - & - & - & $\dagger$ & - & - & - & $\dagger$ & - & - & - & $\dagger$ \\
\hline \multicolumn{14}{|l|}{ Frequency of mines } \\
\hline & Date & 1 & 8 & 31.9 & $<0.001$ & & & & & & & & \\
\hline & Sapling complexity & - & - & - & $\dagger$ & \multirow{3}{*}{\multicolumn{4}{|c|}{ Not tested }} & \multirow{3}{*}{\multicolumn{4}{|c|}{ Not tested }} \\
\hline & Shannon index & - & - & - & $\dagger$ & & & & & & & & \\
\hline & Date $\times$ Shannon index & - & - & - & $\dagger$ & & & & & & & & \\
\hline \multicolumn{14}{|l|}{ Frequency of galls } \\
\hline & Date & 1 & 8 & 15.38 & 0.004 & & & & & & & & \\
\hline & Sapling complexity & - & - & - & $\dagger$ & \multirow{3}{*}{\multicolumn{4}{|c|}{ Not tested }} & \multirow{3}{*}{\multicolumn{4}{|c|}{ No significant terms }} \\
\hline & Shannon index & - & - & - & $\dagger$ & & & & & & & & \\
\hline & Date $\times$ Shannon index & - & - & - & $\dagger$ & & & & & & & & \\
\hline \multicolumn{14}{|c|}{ Predator abundance } \\
\hline & Date & 1 & 7 & 9.76 & 0.017 & - & - & - & $\dagger$ & & & & \\
\hline & Sapling complexity & - & - & - & $\dagger$ & 1 & 5 & 7 & 0.046 & \multirow{3}{*}{\multicolumn{4}{|c|}{ No significant terms }} \\
\hline & Shannon index & 1 & 7 & 10.88 & 0.013 & 1 & 5 & 4.73 & 0.081 & & & & \\
\hline & Date $\times$ Shannon index & 1 & 7 & 10.44 & 0.014 & - & - & - & $\dagger$ & & & & \\
\hline
\end{tabular}

Num $d f$ numerator degrees of freedom, Den $d f$ denominator degrees of freedom, $\uparrow$ removed during model simplification, not tested no observations made for response variable

Information Criterion (AIC) (Crawley 2007). AIC measures the lack of fit of the model; the model with the lower AIC is to be preferred (Burnham and Anderson 2002). If the difference in AIC between two models was smaller than 2, empirical support for the model with the lower AIC was assumed to be substantially better (Burnham and Anderson 2002). Results for each response variable and tree species are presented in Table 1. To ensure that the assumptions of all tests were met, model residuals were inspected for normality and homogeneity of variances.

\section{Results}

Leaf area loss of tree saplings

By the end of the observation season, leaf area loss was generally higher in both maple species compared to beech (one-way ANOVA, sum of squares $=0.1$, mean of squares $\left.=0.06, F_{2,23}=61.18, P<0.001\right)$. Beech saplings had an average loss of $1.5 \%$ leaf area per leaf, whereas leaf area loss was more than twice as high in Norway maple (3.6\%, Tukey HSD, $P<0.001)$. Leaf area loss in sycamore maple was highest (five times higher compared to beech, 7.6\%, Tukey HSD, $P<0.001$ ).

Damage increased with season (LME, $F_{1,8}=49.15$, $P<0.001)$ and the response pattern remained constant in June and August. In August, leaf area loss was roughly $50 \%$ lower in the most species-rich stands compared to the simple beech stands (Fig. 1a). Relating the damage to canopy tree diversity, leaf area loss on beech declined with increased tree species richness (LME, $F_{1,7}=16.6$, $P=0.005$; Fig. 1a). No diversity-related pattern was found for the two maple species, but leaf area loss in sycamore maple was positively related to sapling complexity (LME, $F_{1,7}=26.59, P=0.001 ;$ Table 1).

Frequency and distribution of mines and galls

Mines were only observed on beech, while galls were abundant on beech and sycamore maple. Mines surveyed on beech were caused by larvae of two species of microlepidopteran moths, Stigmella hemagyrella Kollar and Stigmella tityrella Stainton (Lepidoptera: Nepticulidae). The percentage of leaves infested with mines of Stigmella sp. increased during the season from less than 0.3 to $7.2 \%$ (LME, 

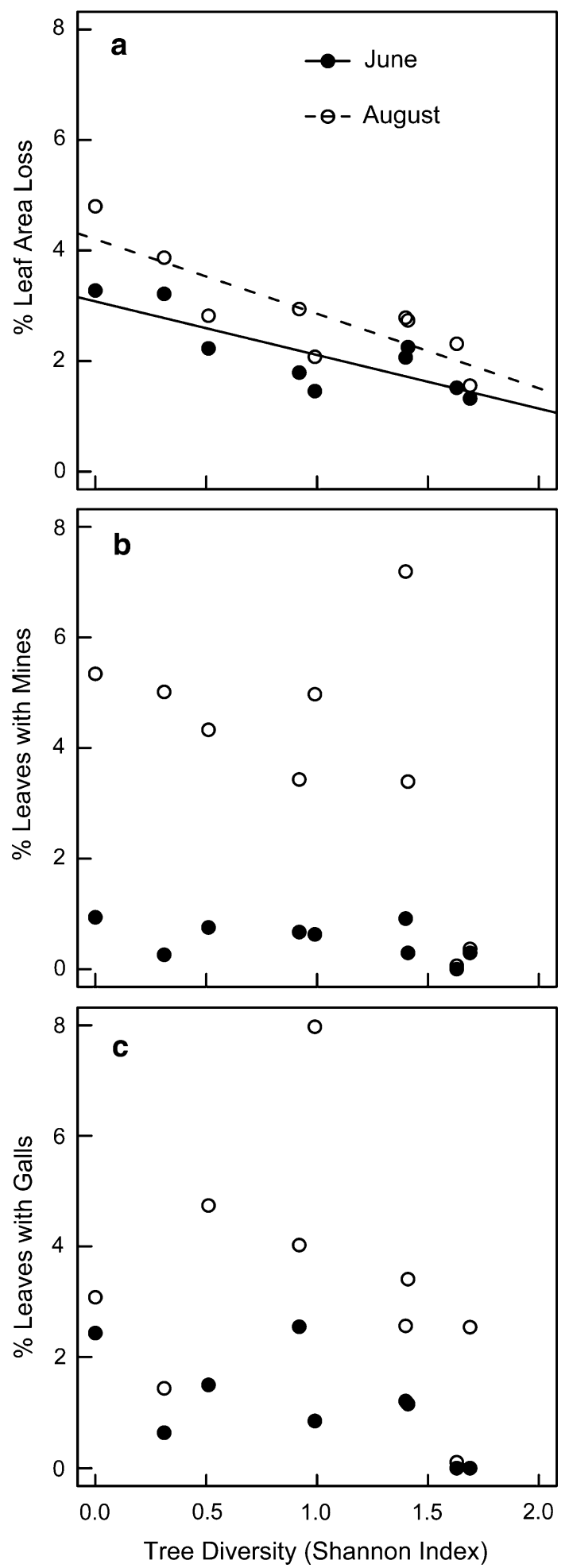

Fig. 1 Leaf damage of beech saplings (means per plot) across a tree diversity gradient ranging from monospecific beech to mixed forest stands in the Hainich National Park. a Percentage leaf area loss per leaf caused by leaf-chewing insects; $\mathbf{b}$ percentage of leaves infested with mines of Stigmella sp.; $\mathbf{c}$ percentage of leaves infested with galls of Hartigiola annulipes and Mikiola fagi. Filled circles June, open circles August
$F_{1,8}=31.9, P<0.001$; Fig. 1 b). In the two most diverse forest stands, there was hardly any increase in mine frequency from June to August. Mine frequency did not correlate with canopy tree diversity (Table 1).

Galls on beech saplings were induced by two gall forming midges (Diptera: Cecidomyiidae), Hartigiola annulipes Hartig and Mikiola fagi (Hart.). The percentage of leaves infested with galls was higher in August compared to June (LME, $F_{1,8}=15.38, P=0.004$ ) and the overall pattern of distribution was similar for both months (Fig 1c). By the end of the season, gall frequency ranged from 0.1 up to $7.9 \%$ infested leaves, but was not related to canopy tree diversity. Galls on sycamore maple were induced by the gall-forming mite Aceria macrorhynchus Nalepa (Acari: Eriophyidae), but showed no response to the factors tested (Table 1).

\section{Arthropod Community structure}

In total, 2,593 arthropods were counted across all plots. Herbivorous and predatory species were grouped into four feeding guilds: leaf chewers, leaf suckers, predators and parasitoids (ESM S3). No adult leaf miners or gall formers were observed. Of all guilds, predators were most abundant (37.2\%), while leaf suckers were the most abundant herbivore feeding guild (19.2\%; Table 2). Parasitoids contributed $3.9 \%$ and leaf-chewing insects amounted to $4.5 \%$ of the total community (Table 2). Identified individuals that do not feed on trees, as well as predators that only prey on minute prey (e.g. predatory mites), were excluded from further analyses.

Both date (LME, $\left.F_{1,7}=9.76, P=0.017\right)$ and canopy tree diversity (LME, $F_{1,7}=10.88, P=0.013$ ) affected relative abundance of predators and parasitoids on beech saplings, but responses differed depending on observation of month (significant date $\times$ Shannon index interaction, LME, $F_{1,7}=10.44, P=0.014$, Fig. 2). In June, the percentage of predators increased with increasing tree diversity by

Table 2 Number of specimens and relative abundance (\% of total) of different insect feeding guilds, sampled or observed on forest plots in the Hainich National Park

\begin{tabular}{lrrrr}
\hline & June & August & Total & $\%$ \\
\hline Leaf chewers & 36 & 81 & 117 & 4.5 \\
Leaf suckers & 164 & 334 & 498 & 19.2 \\
Predators & 191 & 774 & 965 & 37.2 \\
Parasitoids & 51 & 51 & 102 & 3.9 \\
Other & 221 & 690 & 911 & 35.1 \\
Total & & & 2,593 & $99.9^{\mathrm{a}}$ \\
\hline
\end{tabular}

${ }^{a}$ The sum of the percentages falls below $100 \%$ due to rounding 


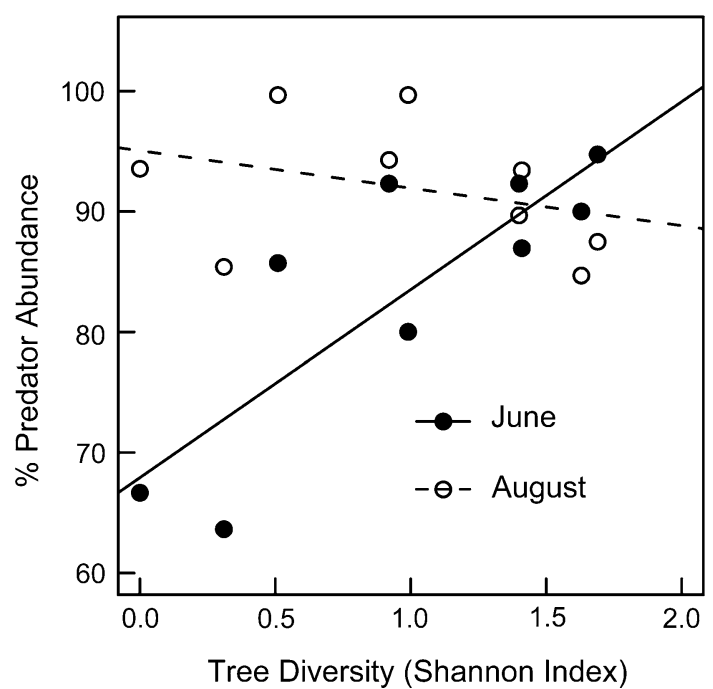

Fig. 2 Relative abundance of predators and parasitoids (per plot) on beech saplings across a tree diversity gradient ranging from monospecific beech to mixed forest stands in the Hainich National Park. Filled circles June, open circles August

roughly $1 / 3$, but in August the abundance of predators and parasitoids decreased with increased tree diversity. The relative abundance of predators and parasitoids was generally high (ranging from 63.6 to $100 \%$ of the total community; Fig. 2).

No significant pattern was found for the relative abundance of predators and parasitoids on sycamore maple. The arthropod community on Norway maple was not affected by canopy tree species richness (LME, $F_{1,5}=4.73$, $P=0.081$; Table 1 ), but related to sapling complexity (LME, $F_{1,5}=7, P=0.046$; Table 1).

\section{Discussion}

Our data support the hypothesis that tree saplings in diverse forest stands are less susceptible to herbivory, but the response was strongly dependent on tree species identity, as well as on herbivore feeding guild. This result is consistent with findings in the boreal zone where no general reduction of herbivore damage in the canopy of mixed forest stands was observed (Koricheva et al. 2006; Vehviläinen et al. 2006, 2007). Vehviläinen et al. (2006) suggest that higher quantities of deciduous trees in conifer forests may explain why in some species-rich stands herbivore damage is not reduced as hypothesised. Deciduous trees have been found to attract more generalist herbivores than conifers. Due to possible dispersal of these generalists across various neighbouring tree species, herbivory rates in forest stands with a higher proportion of deciduous trees might show only subtle or no responses to increased tree species richness (Jactel et al. 2005). Our results do not fully support this assumption. We still found a decrease of leaf area loss on beech saplings, with beech saplings and mature beech trees decreasing in abundance across the deciduous tree diversity gradient-a pattern, which has been explained by mechanisms such as resource concentration (Tahvanainen and Root 1972; Root 1973). The Janzen-Connell hypothesis (Janzen 1970; Connell 1971) also predicts that survival of tree saplings improves with increased parental distance, because herbivores more easily disperse to conspecific saplings growing in dense patches, especially near parent trees. One of the prerequisites to apply these hypotheses is that the herbivores in question are specialists (Risch et al. 1983). The few leaf-chewing species identified in our study feed on various tree species, and cannot be categorised as specialists in the narrow sense of feeding only on one host plant. Nevertheless, some of these species such as Dasychira pudibunda (Lepidoptera: Lymantriidae) show a strong host preference for beech (Schwenke 1978). Such ecological preferences, rather than strict resource specialisation, might have effectively protected beech saplings from leaf area loss in species-rich forest stands.

Our results for miners and gall formers, though specialised insects, showed no evidence for associational resistance. Vehviläinen et al. (2007) suggest feeding preferences as a possible explanation for observed declines of leaf miners in boreal mixed stands, but did not find the same response for gall-forming and leaf-chewing insects. The inconsistent results for chewers, leaf miners and gall-forming insects in different forest types imply that feeding specialisation may be just one of several mechanisms shaping herbivory-tree diversity relationships.

Seasonality and population dynamics after initial colonisation may be important (Otway et al. 2005), but damage patterns in our study were consistent for all observed guilds at both observation dates. This is contrary to observations on deciduous trees in other forest ecosystems, where diversity effects for miners and leaf-chewing insects were more apparent early in the year and then reversed (Vehviläinen et al. 2007).

Examples for in situ top-down control of insect herbivores by predators in forest ecosystems of different diversity are scarce (Riihimaki et al. 2005), but have been shown in experiments (Jactel et al. 2006; Kaitaniemi et al. 2007). However, recent evaluations question the relevance of the enemies hypothesis in forest ecosystems, and relate predator abundance to the presence of certain tree species rather than to tree diversity as such (Schuldt et al. 2008; Vehviläinen et al. 2008). Here, predator abundance on beech saplings was high and increased in the species rich forest stands in June when the leaves where young. This supports the enemies hypothesis (Root 1973; Russell 1989) 
and suggests a diversity-related seasonal increase of topdown control, similar to observations in other ecosystems (Schmitz et al. 2000, Schmitz 2003).

Besides insect herbivores, molluscs also play an important role as herbivores in forest systems (Jennings and Barkham 1975a, b; Cote et al. 2005), and particularly maple is a known food resource for snails and slugs (Pigot and Leather 2008). Herbivory patterns in our examination could not be related to the abundance of snails and slugs at the time of observation, but the higher abundance of molluscs on the most species-rich plots (ESM S2) might be one reason why herbivore damage on maple was not affected by tree diversity. Both maple species were generally more attractive to invertebrate herbivores than beech, but data explaining why beech seems to be less palatable compared to other tree species are scarce. Further investigations should aim to test for species-specific defence mechanisms (e.g. phenolics, condensed tannin and toughness of leaves) or differences in nutrient availability when growing under the same conditions. Norway maple has previously been shown to have a high $\mathrm{N}$ content and thus a narrow $\mathrm{C} / \mathrm{N}$ ratio in the foliage (Hilfreich 1991), which has been used to explain higher herbivore damage (Brötje and Schmidt 2005). The soil $\mathrm{C} / \mathrm{N}$ ratios observed in our study were slightly increased in the simple beech stands, which was contrary to the observed higher herbivore load for beech on these plots. In addition, this should affect all tree species alike, unless differences exist in soil nutrient uptake and utilisation in the plant. Light availability was very low in all stands (0.7-2.7\% of daylight intensity) and insufficient for further height growth of regeneration. Only the growth of Fagus sylvatica and Fraxinus excelsior was slightly sensitive to the marginally fluctuating irradiation (Mölder et al. 2009). Herbivores have previously been shown to be more active in forest gaps (Norghauer et al. 2008). But even though the simple beech stands we studied had higher PAR transmissivity by trend (Mölder et al. 2009), in these stands only beech saplings suffered more herbivore damage compared to saplings in the rather darker mixed forest stands. Differences in light availability amongst our forest stands might be too subtle to have any general effect on sapling herbivory, since we did not investigate fully sun-exposed gaps as did Norghauer et al. (2008).

In conclusion, our study reveals new insights into the effects of tree diversity on levels of herbivory, herbivore and predator abundances in selected tree species at the sapling stage. Tree diversity has only limited explanatory power for the observed patterns in herbivory or insect abundances. By contrast, the identity and abundance of the observed tree species and seasonal effects were much better predictors in many cases. Hence, according to our results, species identity effects may be more important than species diversity per se. While it is difficult to draw such strong conclusions from observational studies alone, it will be interesting to see if tree diversity experiments simulating temperate deciduous forests such as the BIOTREE experiment (Scherer-Lorenzen et al. 2007) will show similar trends.

Acknowledgements Financial support was obtained by the DFG (German Research Foundation) within the framework of the Research Training Group "Graduiertenkolleg 1086: The role of biodiversity for biogeochemical cycles and biotic interactions in temperate deciduous forests". We thank Christoph Leuschner, Frank Thomas, Hermann Jungkunst and Stefan Fleck for coordination of the Research Training Group and also acknowledge Mascha Jacob, Karl M. Daenner, Anja Guckland, Catharina Meinen and Andreas Mölder for providing data on biotic and abiotic plot characteristics. We thank Kyle Rea for proofreading and two anonymous reviewers for helpful comments on the manuscript. All examinations complied with the current law in the country of performance.

\section{References}

Andow DA (1991) Vegetational diversity and arthropod population response. Annu Rev Entomol 36:561-586

Ayres E, Heath J, Possell M, Black HIJ, Kerstiens G, Bardgett RD (2004) Tree physiological responses to above-ground herbivory directly modify below-ground processes of soil carbon and nitrogen cycling. Ecol Lett 7:469-479

Balvanera P, Pfisterer AB, Buchmann N, He JS, Nakashizuka T, Raffaelli D, Schmid B (2006) Quantifying the evidence for biodiversity effects on ecosystem functioning and services. Ecol Lett 9:11461156

Boege K, Marquis RJ (2005) Facing herbivory as you grow up: the ontogeny of resistance in plants. Trends Ecol Evol 20:441-448

Brötje J-H, Schmidt W (2005) Spitzahorn (Acer platanoides) im Kalkbuchenwald. Struktur, Streufall, Samenproduktion und FraBschäden. Forst Holz 60:497-502

Burnham KP, Anderson DR (2002) Model selection and multimodel interference. A practical information-theoretic approach. Springer, New York

Cardinale BJ, Srivastava DS, Duffy JE, Wright JP, Downing AL, Sankaran M, Jouseau C (2006) Effects of biodiversity on the functioning of trophic groups and ecosystems. Nature 443:989-992

Carnus JM, Parrotta J, Brockerhoff E, Arbez M, Jactel H, Kremer A, Lamb D, O'hara K, Walters B (2006) Planted forests and biodiversity. J For 104:65-77

Connell JH (1971) On the role of natural enemies in preventing competetive exclusion in some marine animals and in rain forest trees. In: den Boer PJ, Gradwell GR (eds) Dynamics of populations. Centre for Agricultural Publishing and Documentation, Wageningen, pp 298-312

Cote M, Ferron J, Gagnon R (2005) Invertebrate Predation of Postdispersal Seeds and Juvenile Seedlings of Black Spruce (Picea mariana) in the Boreal Forest of Eastern Canada. Can J For Res 35:674-681

Crawley MJ (2007) The R book. Wiley, Chichester

Forkner RE, Marquis RJ, Lill JT, Le Corff J (2006) Impacts of alternative timber harvest practices on leaf-chewing herbivores of Oak. Conserv Biol 20:429-440

Hanley ME (2004) Seedling herbivory and the influence of plant species richness in seedling neighbourhoods. Plant Ecol 170:35-41

Hanley ME, Fegan EL (2007) Timing of cotyledon damage affects growth and flowering in mature plants. Plant Cell Environ 30:812-819 
Hester AJ, Edenius L, Buttenschon RM, Kuiters AT (2000) Interactions between forests and herbivores: the role of controlled grazing experiments. Forestry 73:381-391

Hilfreich H (1991) Forstliches und Nichtforstliches über den Ahorn. Waldwirt 18:55-59

Hooper DU, Chapin FS, Ewel JJ, Hector A, Inchausti P, Lavorel S, Lawton JH, Lodge DM, Loreau M, Naeem S, Schmid B, Setala H, Symstad AJ, Vandermeer J, Wardle DA (2005) Effects of biodiversity on ecosystem functioning: a consensus of current knowledge. Ecol Monogr 75:3-35

Huttunen L, Niemela P, Peltola H, Heiska S, Rousi M, Kellomaki S (2007) Is a defoliated silver birch seedling able to overcompensate the growth under changing climate? Environ Exp Bot 60:227-238

Jactel H, Brockerhoff EG (2007) Tree diversity reduces herbivory by forest insects. Ecol Lett 10:835-848

Jactel H, Goulard M, Menassieu P, Goujon G (2002) Habitat diversity in forest plantations reduces infestations of the pine stem borer Dioryctria sylvestrella. J Appl Ecol 39:618-628

Jactel H, Brockerhoff E, Duelli P (2005) A test of the biodiversity-stability theory: meta-analysis of tree species diversity effects on insect pest infestations, and re-examination of responsible factors. In: Scherer-Lorenzen M, Körner Ch, Schulze E-D (eds) Forest diversity and function. Temperate and boreal systems. Ecological studies 176. Springer, Berlin, pp 235-262

Jactel H, Menassieu P, Vetillard F, Gaulier A, Samalens JC, Brockerhoff EG (2006) Tree Species diversity reduces the invasibility of maritime pine stands by the bast scale, Matsucoccus feytaudi (Homoptera:Margarodidae). Can J For Res 36:314-323

Janzen DH (1970) Herbivores and number of tree species in tropical forests. Am Nat 104:501-528

Jennings TJ, Barkham JP (1975a) Food of slugs in mixed deciduous woodland. Oikos 26:211-221

Jennings TJ, Barkham JP (1975b) Slug populations in mixed deciduous woodland. Oecologia 20:279-286

Kaitaniemi P, Riihimaki J, Koricheva J, Vehvilainen H (2007) Experimental evidence for associational resistance against the european pine sawfly in mixed tree stands. Silva Fenn 41:259-268

Karban R (2007) Associational resistance for mule's ears with sagebrush neighbors. Plant Ecol 191:295-303

Kluth S, Kruess A, Tscharntke T (2001) Interactions between the rust fungus Puccinia punctiformis and ectophagous and endophagous insects on creeping thistle. J Appl Ecol 38:548-556

Koricheva J, Vehviläinen H, Riihimaki J, Ruohomaki K, Kaitaniemi P, Ranta H (2006) Diversification of tree stands as a means to manage pests and diseases in boreal forests: myth or reality? Can J For Res 36:324-336

Ladd BM, Facelli JM (2005) Effects of competition, resource availability and invertebrates on tree seedling establishment. J Ecol 93:968-977

Le Corff J, Marquis RJ (1999) Differences between understorey and canopy in herbivore community composition and leaf quality for two oak species in Missouri. Ecol Entomol 24:46-58

Leuschner C, Meier IC, Hertel D (2006) On the niche breadth of Fagus sylvatica: soil nutrient status in 50 Central European beech stands on a broad range of bedrock types. Ann For Sci 63:355-368

Leuschner C, Jungkunst HF, Fleck S (2009) Functional role of forest diversity: pros and cons of synthetic stands and across-site comparisons in established forests. Basic Appl Ecol 10:1-9

Löf M, Paulsson R, Rydberg D, Welander NT (2005) The influence of different overstory removal on planted spruce and several broadleaved tree species: survival, growth and pine weevil damage during three years. Ann For Sci 62:237-244

Magurran AE (2004) Measuring biological diversity. Blackwell, Oxford
Maron JL (1997) Interspecific competition and insect herbivory reduce Bush Lupine (Lupinus arboreus) seedling survival. Oecologia 110:284-290

Massey FP, Massey K, Press MC, Hartley SE (2006) Neighbourhood composition determines growth, architecture and herbivory in tropical rain forest tree seedlings. J Ecol 94:646-655

Mauchline AL, Osborne JL, Martin AP, Poppy GM, Powell W (2005) The effects of non-host plant essential oil volatiles on the behaviour of the pollen beetle Meligethes aeneus. Entomol Exp Appl 114:181-188

Mölder A, Bernhardt-Römermann M, Schmidt W (2006) Forest ecosystem research in Hainich National Park (Thuringia): first results on flora and vegetation in stands with contrasting tree species diversity. Waldökologie-Online 3:83-99

Mölder A, Bernhardt-Römermann M, Schmidt W (2008) Herb-layer diversity in deciduous forests: raised by tree richness or beaten by beech? For Ecol Manag 256:272-281

Mölder A, Bernhardt-Römermann M, Schmidt W (2009) Vielfältige Baumschicht-reichhaltige Verjüngung? Zur Naturverjüngung von artenreichen Laubwäldern im Nationalpark Hainich. Allg Forst Jagd 180:49-60

Norghauer JM, Malcolm JR, Zimmerman BL (2008) Canopy cover mediates interactions between a specialist caterpillar and seedlings of a neotropical tree. J Ecol 96:103-113

Otway SJ, Hector A, Lawton JH (2005) Resource dilution effects on specialist insect herbivores in a grassland biodiversity experiment. J Anim Ecol 74:234-240

Pigot AL, Leather SR (2008) Invertebrate predators drive distancedependent patterns of seedling mortality in a temperate tree Acer Pseudoplatanus. Oikos 117:521-530

Pinheiro JC, Bates DM (2000) Mixed-effects models in S and S-PLUS. Springer, New York

Riihimaki J, Kaitaniemi P, Koricheva J, Vehvilainen H (2005) Testing the enemies hypothesis in forest stands: the important role of tree species composition. Oecologia 142:90-97

Risch SJ, Andow D, Altieri MA (1983) Agroecosystem diversity and pest control: data, tentative conclusions, and new research directions. Environ Entomol 12:625-629

Root RB (1973) The organisation of a plant-arthropod association in simple and diverse habitats: the fauna of collards, Brassica olacea. Ecol Monogr 43:95-124

Russell EP (1989) Enemies hypothesis: a review of the effect of vegetational diversity on predatory insects and parasitoids. Environ Entomol 18:590-599

Scherber C, Mwangi PN, Temperton VM, Roscher C, Schumacher J, Schmid B, Weisser WW (2006) Effects of plant diversity on invertebrate herbivory in experimental grassland. Oecologia 147:489-500

Scherer-Lorenzen M, Schulze ED, Don A, Schumacher J, Weller E (2007) Exploring the functional significance of forest diversity: a new long-term experiment with temperate tree species (Biotree). Perspect Plant Ecol Evol Syst 9:53-70

Schmitz OJ (2003) Top predator control of plant biodiversity and productivity in an old-field ecosystem. Ecol Lett 6:156-163

Schmitz OJ, Hambäck PA, Beckerman AP (2000) Trophic cascades in terrestrial systems: a review of the effects of carnivore removals on plants. Am Nat 155:141-153

Schuldt A, Fahrenholz N, Brauns M, Migge-Kleian S, Platner C, Schaefer M (2008) Communities of ground-living spiders in deciduous forests: does tree species diversity matter? Biodivers Conserv 17:1267-1284

Schwenke W (1978) Die Forstschädlinge Europas. Dritter Band. Schmetterlinge. Paul Parey, Hamburg

Sholes ODV (2008) Effects of associational resistance and host density on woodland insect herbivores. J Anim Ecol 77:16-23 
Su Q, Maclean DA, Needham TD (1996) The influence of Hardwood content on Balsam Fir Defoliation by Spruce Budworm. Can J For Res 26:1620-1628

Tahvanainen JO, Root RB (1972) The influence of vegetational diversity on the population ecology of a specialised herbivore, Phyllotreta cruciferae (Coleoptera: Chrysomelidae). Oecologia 10:321-346

Unsicker SB, Baer N, Kahmen A, Wagner M, Buchmann N, Weisser WW (2006) Invertebrate herbivory along a gradient of plant species diversity in extensively managed grasslands. Oecologia 150:233-246

Vehviläinen H, Koricheva J, Ruohomäki K, Johansson T, Valkonen S (2006) Effects of tree stand species composition on insect herbivory of silver birch in boreal forests. Basic Appl Ecol 7:1-11

Vehviläinen H, Koricheva J, Ruohomäki K (2007) Tree species diversity influences herbivore abundance and damage: meta-analysis of long-term forest experiments. Oecologia 152:287-298

Vehviläinen H, Koricheva J, Ruohomäki K (2008) Effects of stand tree species composition and diversity on abundance of predatory arthropods. Oikos 117:935-943. doi:10.1111/j.0030-1299.2008. 15972.x

White JA, Whitham TG (2000) Associational susceptibility of cottonwood to a box elder herbivore. Ecology 81:1795-1803

Wint GRW (1983) Leaf damage in tropical rain forest canopies. In: Sutton SL, Whitmore TC, Chadwick AC (eds) Tropical rain forest: ecology and management British ecological society. Blackwell, Oxford, pp 229-239

Zeide B, Thompson LC (2005) Impact of spring sawfly defoliation on growth of Loblolly Pine stands. South J Appl For 29:33-39 